\title{
Stage IV Rectosigmoid Cancer AJCC v6
}

National Cancer Institute

\section{Source}

National Cancer Institute. Stage IV Rectosigmoid Cancer A/CC v6. NCI Thesaurus. Code C8636.

Stage IV includes: Any T, Any N, M1. M1: Distant metastasis. (AJCC 6th ed.) 